\title{
How effective are impact assessment procedures for ecotourism in developing nations? A case study analysis
}

\author{
D. Hernán Valencia Korosi \\ Australian Centre for Cultural Environmental Research, \\ University of Wollongong, Australia
}

\begin{abstract}
By the late 1980s, ecotourism became officially recognised as a sustainable development strategy, and a way to improve the quality of life of marginalised communities. Yet today it is still a field of contested discourses and paradigms, especially in developing countries, where environmental legislation is still often ambiguous and not powerful enough to ensure enforcement of the outcomes of planning and assessment instruments. It has been argued that impact assessment procedures are not only meant to identify potential impacts of a proposed development, but should endorse responsible environmental management practices, and active community involvement in the decision-making process. This study compares the theory and practice behind ecotourism assessment and management of the La Escobilla Turtle Sanctuary and the Xixim Ecolodge through the analysis of initial project impact assessments, semi-structured interviews with representatives of different sectors of Mexican society, and a survey of tour operators. It aims to determine whether or not current Mexican environmental legislation for assessment procedures is providing an adequate framework for the adoption of sustainable tourism practices. It is argued that impact assessment procedures often poorly incorporate social and cultural variables, and hence fail to acknowledge tour operators' management and operation skills, and therefore decrease the quality of impact prediction and monitoring strategies for future ecotourism management.

Keywords: La Escobilla, Xixim Ecolodge, ecotourism, impact assessments, sustainable development, environmental legislation, developing countries.
\end{abstract}




\section{Introduction}

Today, ecotourism is the fastest growing sector of the tourism industry (Almeyda et al. [1]). Tourists around the world are becoming more aware of the footprints and impacts of traditional mass tourism, preferring responsible and sustainable travel experiences (Honey [2]). This trend has led to what different authors have called the "greening of the tourism industry", characterized by the incorporation of terms such as "eco", "sustainable", and "alternative” but with no essential changes from mass tourism practices (Buckley [3]; Farquharson [4]; Fennell and Dowling [5]; Pardo [6]) . Environmental planning and assessment practices have also played a crucial role in the greening process as they have become tools to control the development of proposals that might have potential impacts on the environment, and on the wellbeing of local populations (O'Faircheallaigh [7]) .

Ecotourism projects are not exempt from procedures requiring the development of Environmental and Social Impact Assessments (EIA and SIA respectively) to demonstrate adequate protection and impact monitoring strategies (García [8]). In Mexico, EIA procedures are mandatory under the 1988 Environmental Protection and Ecological Equilibrium General Law (LGEEPA) that dictates which components and standards should be observed when developing such evaluations (Cámara de Diputados del H. Congreso de la Unión [9]). At the same time, the LGEEPA, in agreement with other legislation, regulates the protection of ecosystem services ensuring that impact assessment procedures are enforced considering all components of the environment/society that could be affected by the development (SEMARNAT [10]). However, this is not necessarily the case in reality, as current EIA procedures are hardly promoting sustainable and responsible practices, and SIA procedures are not enforced by law, leaving a gap in the overall assessment of projects (Becerra [11]; Brito [12]; Juárez [13]; Sangines [14]). Therefore, it is important to understand how the theory and practice behind ecotourism has been addressed, and whether or not Mexican environmental legislation has allowed the adoption of adequate planning and assessment procedures for the implementation of responsible ecotourism practices.

This paper forms part of a broader PhD project aiming to compare Mexican and Australian environmental and social impact assessment procedures for ecotourism. The study uses several different methods to analyse the effectiveness of EIA/SIA including the study of legislation at a national scale, interviews of government, NGO and academia representatives, and a tour operators' survey. In this paper I identify the issues behind the theory and practice of ecotourism impact assessments focusing on two case studies on the Pacific and Caribbean coasts of Mexico. The La Escobilla Turtle Sanctuary in the coast of Oaxaca while the Xixim Ecolodge is on the coast of Yucatan.

Both the La Escobilla Turtle Sanctuary and the Xixim Ecolodge have undergone EIA and SIA procedures in the past. However, final reports have shown little scientific and social based knowledge to support current management and impact mitigation strategies. In addition, such procedures have not addressed issues concerning administrative and operation skills of tour 
operators to enable adequate management. Limited funding and government support, and the deficient application of impact assessment procedures have triggered a series of issues within these two enterprises that threaten their success and need to be resolved appropriately.

\section{Methods}

\subsection{Case studies}

Case studies were selected according to their proximity to protected areas or areas of environmental and/or heritage significance. They are located on Mexican coasts, one in the Caribbean coastal town of Celestun, and the other in the Pacific coastal town of La Escobilla. Both have been chosen to compare experiences each ecotourism business had in the understanding of EIA and SIA practices prior, during and after the implementation of their activities, and how this understanding reflects the current management practices each enterprise has adopted for the prevention of potential impacts.

Additionally, during 2010, a 30-question survey was designed for tour operators to understand the efficiency of the planning process before the implementation of the business. The survey consisted of five sections aiming to relate the outcomes of the initial impact planning and assessment process with current management practices. Each section had five questions relating to the general planning, impact planning, community participation, sustainable development and demographic information from each of the tour operators (Table 1).

Table 1: $\quad$ Survey structure and design.

\begin{tabular}{|l|l|}
\hline \multicolumn{1}{|c|}{ Section } & \multicolumn{1}{c|}{ Description } \\
\hline A. Planning & $\begin{array}{l}\text { - Conceptualization and understanding of ecotourism theory and practice } \\
\text { - Benefits and constraints of ecotourism enterprises } \\
\text { - Government support and funding }\end{array}$ \\
\hline $\begin{array}{l}\text { B. Impact } \\
\text { Planning }\end{array}$ & $\begin{array}{l}\text { - Quality of EIA/SIA procedures } \\
\text { - Mitigation and preventive measures }\end{array}$ \\
\hline $\begin{array}{l}\text { C. Community } \\
\text { Participation }\end{array}$ & $\begin{array}{l}\text { - Community involvement in the EIA/SIA decision-making process } \\
\text { - Value of local knowledge }\end{array}$ \\
\hline $\begin{array}{l}\text { D. Sustainable } \\
\text { Development }\end{array}$ & $\begin{array}{l}\text { - Sustainability of the business } \\
\text { - Benefits of the project for the local environment } \\
\text { - Benefits of the project for the local community }\end{array}$ \\
\hline $\begin{array}{l}\text { E. Demographic } \\
\text { information }\end{array}$ & $\begin{array}{l}\text { - Age, origin, level of education, family structure, and transportation } \\
\text { behaviours }\end{array}$ \\
\hline
\end{tabular}




\subsection{Interviews}

During 2010 and 2011, in-depth, semi-structured interviews were undertaken in Spanish, with key informants of Mexican society involved in ecotourism planning and management in order to identify and understand, on the one hand, ongoing issues with impact assessment procedures, and on the other hand, to compare the theory and practice behind the implementation of EIA and SIA practices. Key informants were NGO representatives, government officials, and academics with ample experience in the sector (Table 2). An iterative comparative analysis of the interview data was conducted in order to gain indepth knowledge of the benefits and constraints of the ecotourism industry. A qualitative research approach was appropriate as the group of key informants were interviewed on an individual and personalised basis following the method used by Matysek and Kriwoken [15]. It is important to highlight that names of participants have been kept confidential as part of an ethics agreement.

Table 2: $\quad$ Interviewees from different sectors of the Mexican society.

\begin{tabular}{|l|l|l|}
\hline Sector & Institution & Department/Office \\
\hline \multirow{5}{*}{ Government } & $\begin{array}{l}\text { National Commission for the } \\
\text { Development of Indigenous } \\
\text { Communities - CDI }\end{array}$ & $\begin{array}{l}\text { - Department of Alternative Tourism } \\
\text { within Indigenous Communities }\end{array}$ \\
\cline { 2 - 3 } & $\begin{array}{l}\text { Mexico City Natural Resources } \\
\text { Secretariat-SMA }\end{array}$ & $\begin{array}{l}\text { Consultation and Planning General } \\
\text { Directorate }\end{array}$ \\
\cline { 2 - 3 } & $\begin{array}{l}\text { National Commission of Natural } \\
\text { Protected Areas - CONANP }\end{array}$ & $\begin{array}{l}\text { - Natural Protected Areas Conservation } \\
\text { Program }\end{array}$ \\
\cline { 2 - 3 } & $\begin{array}{l}\text { Secretary of Environment and } \\
\text { Natural Resources - SEMARNAT }\end{array}$ & $\begin{array}{l}\text { - Tourism and Urban Development } \\
\text { Directorate }\end{array}$ \\
\cline { 2 - 3 } & Tourism Secretariat - SECTUR & $\bullet$ General Director's Office \\
\hline \multirow{5}{*}{ NGO } & $\begin{array}{l}\text { Oaxaca's Coast Westland Network } \\
\text { Association - RHCO }\end{array}$ & $\bullet$ Regional Ecotourism Office \\
\hline \multirow{5}{*}{ Academia } & University of the Sea - UMAR & $\bullet$ Resource Institute \\
\cline { 2 - 3 } & $\begin{array}{l}\text { Mexico National Autonomous } \\
\text { University - UNAM }\end{array}$ & $\bullet$ Industry Institute \\
\cline { 2 - 3 } & National Institute of Ecology - INE & $\bullet$ Department of Ecosystem Studies \\
\hline
\end{tabular}

\section{Results}

\subsection{Case studies}

\subsubsection{La Escobilla Sanctuary, Santa María Tonameca, Oaxaca, Mexico}

La Escobilla Turtle Sanctuary is located $34 \mathrm{~km}$ southeast of San Pedro Pochutla and 30 min southwest of Puerto Escondido in the rural coastal town of La Escobilla (Fig. 1B). The town was populated during the 1940 s by Indigenous Zapoteco immigrants from el Lagartero, Pochutla, who became illegal egg poachers of the Olive ridley turtle (Lepidochelys olivacea) in the 1950s, and 
continued for almost 30 years due to the lack of suitable agricultural produces and other subsistence resources. By 1970, the Mexican government introduced a ban to stop the illegal extraction of eggs resulting in a tragic confrontation between the inhabitants and the Navy officers in which a local boy was badly injured. This event triggered a change in the mentality of the local people who now protect the turtles through the ecotourism (Macedo [16]). The Sanctuary is operated by the Sociedad Cooperativa El Santuario de la Tortuga La Escobilla (hereafter, the Cooperative), which is formed by members of four local families. Members of the Cooperative have low education and live in marginalised conditions. They have being working on the ecotourism business since 1997 aiming to run a successful enterprise and adopt sustainable living practices to improve their quality of life and protect the populations of the Olive ridley turtle. Since the formation of the Sanctuary, members of the Cooperative have struggled to operate an enterprise, which was thought to provide better financial opportunities to their members through the promotion of conservation-oriented activities.

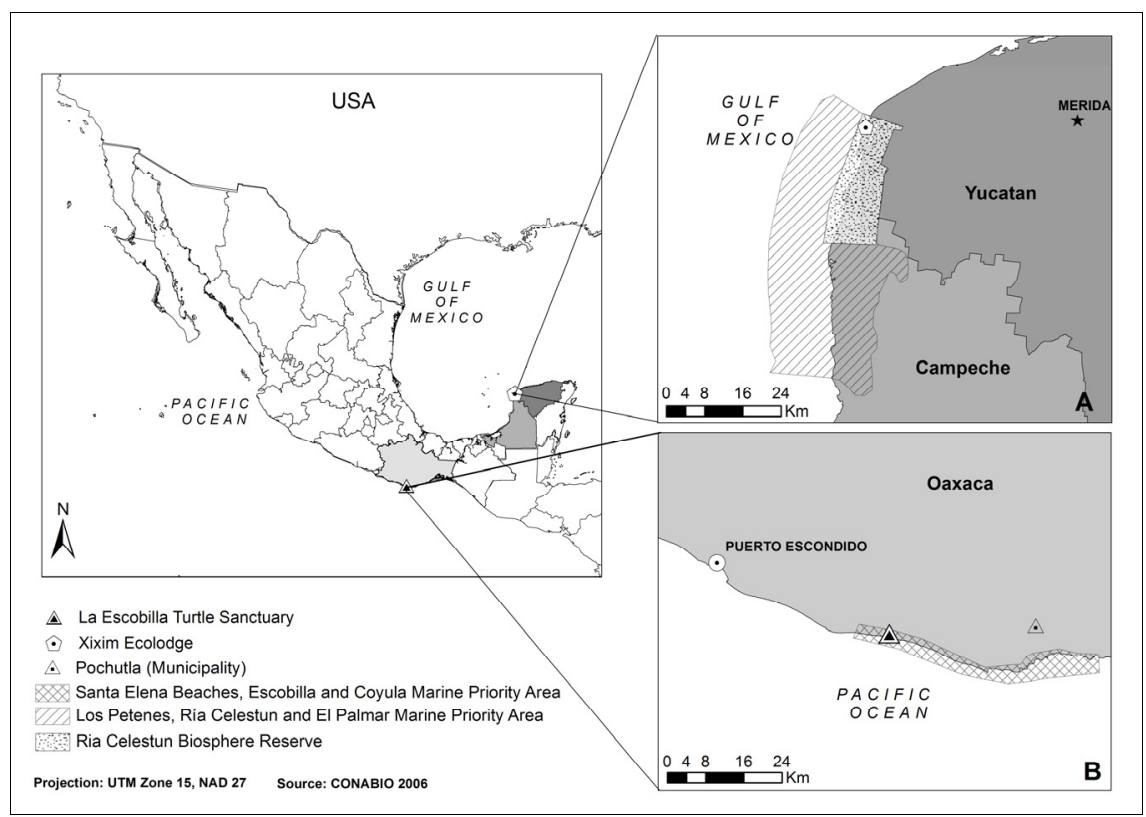

Figure 1: Location map. A) Xixim Ecolodge within the Ria Celestun Biosphere Reserve and the Los Petenes, Ria Celestun and El Palmar Marine Priority Area. B) La Escobilla Sanctuary within the Santa Elena Beaches, Escobilla and Coyula Marine Priority Area (Source: CONABIO 2006).

Activities such as wildlife watching and guided tours to nesting sites are the most popular within the Sanctuary. Costs of wildlife watching tours to the estuary on a "cayuco" range from \$15 to \$25 MX pesos for children and adults 
respectively, and guided tours to the nesting sites are $\$ 100 \mathrm{MX}$ pesos per person during the nesting season. In addition, the Cooperative has to pay the National Commission for Protected Areas (CONANP) an access fee of \$70 MX pesos per person, which, according to the Sanctuary Manager, represents a loss in the overall profits of the business. Simultaneously, the restaurant (Fig. 2A) provides a great variety of local seafood dishes and Mexican "antojitos" at a reasonable price. Antojitos are tasty local made snacks such as "tacos", "enchiladas", "sopes" and "quesadillas". A conference centre (Fig. 2B) has also been built to serve as a classroom for workshops and other group activities becoming an additional source of income when rented to external parties. Accommodation in rustic cabins (Fig. 2C) is not highly successful even though tariffs are modestly cheap, ranging from $\$ 250$ to $500 \mathrm{MX}$ pesos for 2 or 3 bed cabins. Camping is not popular, but tents can be hired for \$100-140 MX pesos, with an extra \$50 MX pesos fee for the camping sites. Additionally, members of the Cooperative work on a daily basis "communal salary" named "tequio", where every member has a designated task, to be fulfilled during the day. Through this system, the overall daily profits are evenly distributed between members. However, profits are not enough to fulfil each member's living needs; hence they are struggling to successfully operate the business. The Sanctuary has also established the use of green technologies with the objective of reducing environmental impacts such as Biodigestors and composting systems.

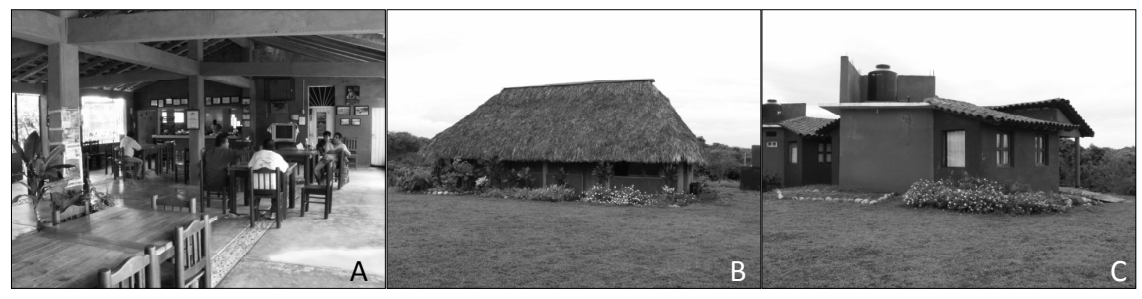

Figure 2: A) Restaurant, B) conference centre, and C) rustic cabins (Source: Valencia 2010).

\subsubsection{Xixim Ecolodge, Celestun, Yucatán, Mexico}

The Xixim Ecolodge (hereafter the Ecolodge) is located $2 \mathrm{~km}$ north-east of the port of Celestun in the Yucatan Peninsula enclave within the Ria Celestun Biosphere Reserve (Fig 1A). The Ecolodge is a successful private luxurious business aiming to provide an eco-friendly, educational and relaxing experience to visitors, with additional promotion of interpretative and educational components. The total area of the project comprises 25 ha with only $14,445.25 \mathrm{~m}^{2}$ being built. All infrastructures are located $80 \mathrm{~m}$ outside of the Zona Federal Marítimo Terrestre (ZOFEMAT), a designated buffer zone where no infrastructure can be built according to the Mexican Coastal Development Regulation. This measure was also planned in order to preserve the coastal dune ecosystem and protect the Ecolodge against hurricanes and other natural disasters. The rest of the 25 ha have been left fairly untouched, and two walking 
tracks have been built to encourage guests to admire and learn about the local flora and fauna of the surrounding area, and, to a greater extent, to contribute to the conservation of the Biosphere Reserve. Each room at the Ecolodge provides a series of colour printed brochures to be used by guests during their trekking experience and to promote education and interpretation of local biodiversity. Furthermore, a series of green technologies have been introduced to reduce the impact on the environment such as solar heating for swimming pools (Fig. 3A) and a SIRDO system for solid wastes recycling and management (Fig. 3B) among others. However, due to the lack of public electricity services, the Ecolodge uses a diesel generator (Fig. 3C) to power electronic and electrical devices such as refrigerators, water pumps, lighting system, and electronic appliances.

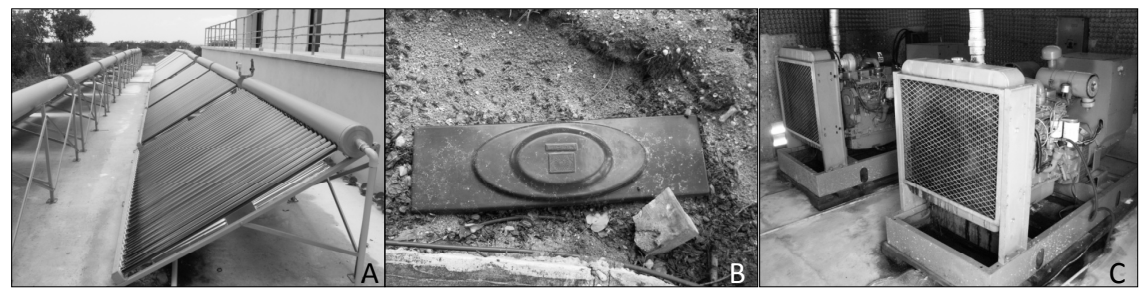

Figure 3: A) Solar heating systems, B) SIRDO solid waste recycling system, and C) diesel generator (Source: Valencia 2010).

Even though the Ecolodge does not provide ecotouristic services on site, it has numerous business partners which offer and provide services such as wildlife watching, nature safaris or canoeing. Additionally, the Ecolodge has established partnerships with local environmental organizations to promote environmental consciousness and awareness among the local population and other interested groups. According the Ecolodge manager, these partnerships have promoted initiatives like releasing turtles into the ocean, an activity that has become popular among local schools.

Finally, some of the issues determining the number of visitors to the Ecolodge include the quality of the access roads, which are often in bad shape, becoming flooded during the rainy season, worsening the access to the Ecolodge. Resolution of this situation has been tried in consultation with the National Commission for Protected Areas (CONANP) and the Celestun Municipality, but until 2011, such improvements have not been made. The costs of accommodation range from \$276-\$330 USD in low season (May-November) to \$290-\$383 USD per day in peak season (December-April).

\subsection{Responses from interviewees}

Most interviewees agree that ecotourism endeavours are subjected to a series of problems during their implementation depending, on the degree of planning and management skills. On the one hand, EIA/SIA procedures are relatively expensive and intricate, requiring a complex set of skills and sufficient amount 
of planning and time (representative of the Department of Ecosystem Studies, INE, 2010). However, time and money are not often available resulting in deficient decisions and irresponsible practices (representative of the Consultation and Planning General Directorate, CDI, 2010). At the same time, private enterprises are usually run by educated people with adequate knowledge of the administrative and managerial components of the business, with significant financial resources, and higher education degrees. In addition, these operators have a clear understanding of the environmental components of the enterprise, and have the means to ensure its protection through adequate EIA/SIA and management practices (representative of the General Director's Office, SECTUR, 2011). On the other hand, indigenous and rural community endeavours often struggle to balance the financial and conservation components of the business, resulting in poor implementation of effective protection and impact management strategies, hence increasing the number of impacts within the site (representative of the Department of Alternative Tourism within Indigenous Communities, CDI, 2010). Frequently, these ventures are under pressure to keep operating and usually require a complex set of skills which is often lacking among operators, as they often modify their farming habits to become tour operators within a short period of time (representative of the Natural Protected Areas Conservation Program, CONANP, 2010). Furthermore, the lack of adequate management skills due to poor education and living conditions directly affects the quality and success of the business (representatives of the Resource and Industry Institutes, UMAR, 2010).

In response, impact assessment procedures often fail to capture these issues, as well as the needs and interests of tour operators, paying more attention to legal requirements to gain approval. The result is that other sections of the evaluation are being left unattended (representative of the Regional Ecotourism Office, RHCO, 2010). Another issue is that tour operators are not aware of land uses and ownership conflicts, leading to the implementation of unsuitable infrastructure and activities resulting in unidentified and poorly manageable impacts (representative of the Assessment and Environmental Impact Directorate, SMA, 2010). Finally, tour operators fail to embrace the principles of ecotourism, and their practices more closely resemble like traditional mass tourism. In this sense, tour operators should become aware of the impacts of the activities they promote by adopting more responsible and sustainable practices (representative of the Tourism and Urban Development Directorate, SEMARNAT, 2010, and representative of the Institute of Ecology, UNAM, 2011). Additionally, answers to the survey have provided evidence of the initial planning process, as well as information regarding administrative procedures before the implementation of each project. In regards to Section A, tour operators from the Cooperative were not aware of what ecotourism means and what benefits and constraints could be envisaged from the establishment of such an enterprise. However, respondents agree that some sort of benefit would be obtained from the venture. Surprisingly, owners of the Ecolodge experienced the same problem until appropriate research was undertaken. In regards to the EIA/SIA decision-making process, the Sanctuary and the Ecolodge members described it as a fair and inclusive process 
where their interests and concerns were acknowledged and reflected within the final report. Not surprisingly, answers to Section B showed little understanding of impact assessment procedures and the likely impacts of ecotourism activities. Section C, on the other hand, showed concerns from tour operators in regards to community involvement in the EIA/SIA process and the importance of acknowledging operator's interests. In Section D, tour operators confidently stated that the business has generated tangible benefits for both the environment and the local community by protecting both turtle nesting sites and the overall habitat of the Olive ridley turtle. On the other hand, the creation of employment which improves the quality of life of local inhabitants, as well as promoting a sense of ownership among participants, has indirectly increased the importance of their work for the benefits of the protected area. Finally, Section E showed interesting facts about participants and the way they behave towards the project. On the one hand, participants of the Sanctuary are of mature age, living close to the project site, and are proactive to engage in practices to increase their management capacities. However, the lack of possible replacements to undertake management, operation and administrations positions within the projects, threatens the permanency of the business in the long run.

\section{Discussion}

It is clear that several issues are affecting the conceptualisation and hence the implementation of impact assessment procedures for ecotourism according to the analysis of the case studies (Table 3). Firstly, EIA/SIA procedures often failed to analyse tour operator's management and operation skills, in order to acknowledge their financial capabilities to administrate and manage the ecotourism business. Nevertheless, operators have constantly participated in onsite capacity-building workshops to enhance their knowledge of the business. However, a clear understanding of critical principles such as follow-up strategies, and adaptive management schemes is often lacking. It is imperative these issues be resolved if tour operators decide to compete and succeed within the tourism industry. Secondly, private enterprises successfully operate their businesses at an increase level of comfort to provide guests with a luxurious, healthy and relaxing experience. However, they will need to consider not to trespass the boundaries between traditional mass tourism and ecotourism as this will create unforeseeable impacts in the long run. Thirdly, although the extensive use of alternative technologies to minimise the impact on the environment is a suitable option, adequate prevention of potential impacts is not guaranteed, constant monitoring and maintenance of such technologies is required. On the other hand, complex and expensive impact assessment procedures should evolve into procedures that are simpler, cheaper and more holistic. Assessment procedures should ideally include considering operators' needs and interests, and include effective environmental protection measures to ensure the adequate management of natural and cultural resources. Using the Sanctuary as an example, after fifteen years of constant operation, no major improvements to their quality of life have been experienced, and issues with the operation have 
arisen in spite of the benefits the Cooperative has achieved. In 2011, the Cooperative was heavily fined by Environmental Protection Authority (PROFEPA) after failing to register the EIS on time. Until this legal requirement is amended, activities have been stopped and the continuation of the project is threatened as, according to the Sanctuary Manager, members do not have the means to cover such fines. Finally, in comparison with developed countries, issues often reside in the accuracy and quality of EIA/SIA guidelines as they are still ambiguous and complex procedures are hard to understand by local tour operators.

Table 3: $\quad$ Positive and negative outcomes from the EIA/SIA procedures within the two case studies.

\begin{tabular}{|c|c|c|c|c|}
\hline \multicolumn{2}{|c|}{ Cases } & EIA procedures & SIA procedures & $\begin{array}{l}\text { Ecotourism } \\
\text { principles and } \\
\text { practices }\end{array}$ \\
\hline \multirow{2}{*}{ 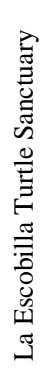 } & 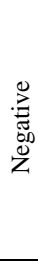 & $\begin{array}{l}\text { - } \text { Poorly executed } \\
\text { - } \text { Management does not } \\
\text { reflect EIA outcomes } \\
\text { - No monitoring, } \\
\text { prevention or follow-up } \\
\text { measures } \\
\text { - Poor scientific base } \\
\text { knowledge }\end{array}$ & $\begin{array}{l}\text { - Poor relation with EIA } \\
\text { components } \\
\text { - No monitoring or follow- } \\
\text { up strategies. } \\
\text { - Deficient management and } \\
\text { operations skills } \\
\text { - No financial analysis }\end{array}$ & $\begin{array}{ll}\text { - } & \text { Poorly } \\
& \text { understood } \\
\text { - } & \text { Hardly } \\
& \text { financially } \\
& \text { sustainable }\end{array}$ \\
\hline & 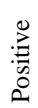 & $\begin{array}{l}\text { - Awareness of the need } \\
\text { to protect the } \\
\text { environments }\end{array}$ & $\begin{array}{l}\text { - Sense of ownership and } \\
\text { protection of local } \\
\text { knowledge }\end{array}$ & $\begin{array}{l}\text { - Ad hoc education } \\
\text { and interpretation } \\
\text { strategies }\end{array}$ \\
\hline \multirow{2}{*}{ 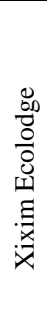 } & 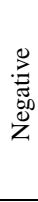 & $\begin{array}{l}\text { - Sloppy } \\
\text { - No monitoring or } \\
\text { follow-up } \\
\text { - Poor scientific base } \\
\text { knowledge } \\
\text { - Justification tool } \\
\end{array}$ & 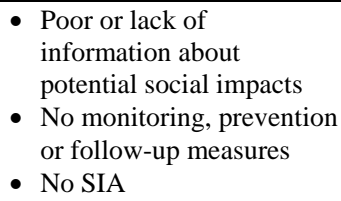 & $\begin{array}{ll}\text { - } & \text { Ambiguous } \\
\text { - } & \text { No essential } \\
\text { changes from } \\
\text { mass tourism } \\
\text { - Hardly financially } \\
\text { sustainable }\end{array}$ \\
\hline & 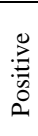 & $\begin{array}{l}\text { - Awareness of } \\
\text { environmental } \\
\text { protection } \\
\text { - Preventive measures }\end{array}$ & $\begin{array}{l}\text { - Partnerships with other } \\
\text { businesses }\end{array}$ & $\begin{array}{l}\text { - Advance } \\
\text { education and } \\
\text { interpretation } \\
\text { strategies }\end{array}$ \\
\hline
\end{tabular}

\section{Conclusions}

The theory and practice of ecotourism, as conceived in the developed world, has not yet been fully accepted or adopted in Mexico, which shows discrepancies between the principles and actual management and operation of ecotourism practices. Perhaps the main reason is that tour operators usually lack appropriate skills to manage and operate such businesses due to the lack of adequate knowledge about the intrinsic relationships that rule the natural world. Socioeconomically speaking, ecotourism per se is a business and a sustainable development strategy, and as such, it needs to fulfil the operators' financial and living necessities in order for them to continue investing time and money in the 
operation and maintenance of the venture. If these components of the enterprise are not effectively addressed, potential impacts will continue to arise, diminishing the value of the natural environment and consequently the value of the enterprise. In this way, impact assessment procedures play a fundamental role by identifying adequate pathways towards effectively managing potential impacts. At the same time, Mexican impact assessment standards provide a vague but complex framework for tour operators to address all components of the planning process. Identification, monitoring and follow-up strategies of potential impacts require sound and reliable scientific methodologies in order for tour operators to adequately plan and operate their enterprises. Such methodologies, which are applied by experts, should be communicated in a simple and effective way so that tour operators can understand the implications of their implementation. In this sense, tour operators need to increase their understanding of the theory and practices behind ecotourism, as well as mastering a different set of skills if they wish to become competitive, successful, and sustainable enterprises. At the same time, they will need to become capable of adopting sound conservation strategies in order to preserve the natural and cultural environment. Finally, adequate management of natural resources has become an essential task for tour operators, and requires numerous skills and adequate funding to effectively operate. Therefore, ecotourism businesses need to integrate educational and interpretative components into their advertised activities to make sure guests leave with the appropriate knowledge to share the information with other people, and thus continually promote responsible tourism practices.

\section{Acknowledgements}

I would like to thank the Mexican National Council for Science and Technology (CONACyT) for their sponsorship of this project. I would also like to deeply thank my supervisors (Lesley Head and John Morrison) for helping me with the discussion.

\section{References}

[1] Almeyda A.M., Broadbent E.N., Wyman M.S. and Durham W.H., Ecotourism impacts in the Nicoya Peninsula, Costa Rica, International Journal of Tourism Research, pp. 17, 2010.

[2] Honey M., Ecotourism and Sustainable Development: Who own Paradise?, Island Press: Washington, pp. 551, 2008.

[3] Buckley R., A Framework for ecotourism, Annals of Tourism Research, 21 (3), pp. 661-669, 1994.

[4] Farquharson M., Ecotourism: A dream diluted-Environmental theory turns commercial ploy, Business Mexico, 2 (6), pp. 8-11, 1992.

[5] Fennell D.A. and Dowling R.K., Ecotourism Policy and Planning: Stakeholders, Management and Governance (Chapter 17), eds. D.A. 
Fennell and R.K. Dowling, Ecotourism Policy and Planning, CABI, pp. 331-343, 2003.

[6] Pardo G.L., Políticas públicas y ecoturismo en comunidades indígenas de México, Teoría y Praxis, (5), pp. 33-50, 2008.

[7] O'Faircheallaigh C., Environmental agreements, EIA follow-up and aboriginal participation in environmental management: The Canadian experience, Environmental Impact Assessment Review, (27), pp. 319-342, 2007.

[8] García G., Evaluación de Impacto Ambiental, Un Proceso Multidisciplinario, Derecho Ambiental y Ecología, (30), pp. 45-46, 2009.

[9] Cámara de Diputados del H. Congreso de la Unión, Ley General del Equilibrio Ecológico y Protección al Ambiente, Gobierno de los Estados Unidos Mexicanos, Ciudad de México, pp. 107, 2011.

[10] SEMARNAT, Requisitos y Especificaciones de Sustentabilidad del Ecoturismo: Requirements and Regulations of Sustainability in Ecotourism, pp. 77, 2006.

[11] Becerra R.E.A., La Evaluación de Impacto Ambiental en México. Situación Actual y Perspectivas Futuras, Derecho Ambiental y Ecología, (30), pp. 5153, 2009.

[12] Brito P., La Evaluación de Impacto Ambiental, un instrumento de política ambiental indispensable, pero carente de reglas claras y objetivos en México, Derecho Ambiental y Ecología, (30), pp. 47-49, 2009.

[13] Juárez J.R., La Evaluación de Impacto Ambiental: La Necesidad de Actualizar este Instrumento a la Luz de Nuevos Modelos, Derecho Ambiental y Ecología, (30), pp. 55-57, 2009.

[14] Sangines A.G., Política ambiental en México: Génesis, desarrollo y perspectivas, Boletin ICE Economico, (821), pp. 163-175, 2005.

[15] Matysek K.A. and Kriwoken L.K., The Natural State: Nature-Based Tourism and Ecotourism Accreditation in Tasmania, Australia, Journal of Quality Assurance in Hospitality and Tourism, 4 (1/2), pp. 129-146, 2003.

[16] Macedo J.A., De Actor a Sujeto: El Camino al Ecoturismo de la "Cooperativa Santuario de la Tortuga de La Escobilla (ANP)", Oaxaca., Universidad Autónoma Metropolitana, Unidad Xochimilco, División de Ciencias Sociales y Humanidades, Tesis de Maestría, UAM, 274, 2010. 